Dominik Mierzejewski

(Uniwersytet Łódzki)

\title{
Chińskie elity władzy XVI kadencji wobec świata zewnętrznego
}

Publikowane przez władze chińskie dokumenty dotyczące polityki zagranicznej, m.in. wydana 22 grudnia 2005 r. Biała Księga Chińska droga pokojowego rozwoju (Zhongguo de heping fazhang daolu), wymagaja głębszego zrozumienia i analizy przede wszystkim z uwagi na sposób postrzegania świata zewnętrznego przez elity władzy Chińskiej Republiki Ludowej ${ }^{1}$. Elity bowiem decydują o kształcie polityki zagranicznej, podejmują decyzje w sprawach kluczowych dla państwa, jego rozwoju i przyszłości. Pytanie zatem o czynniki warunkujące postrzeganie innych uczestników stosunków międzynarodowych i próba udzielenia obiektywnej odpowiedzi wydają się nader zasadne.

Państwo chińskie ma tradycję i kulturę liczącą ponad 5000 lat. Omawiane zagadnienie dotyczące elit władzy zostanie poddane analizie na trzech płaszczyznach:

- cywilizacyjno-kulturowej;

- zmian wewnętrznych w ChRL;

- koncepcji zapożyczonych z zachodnich nauk społecznych.

\section{Definicja i kosmopolityzm elit}

Ze względu na właściwe zrozumienie problemu należy wyjaśnić samo pojęcie elity władzy. Elity, według Blackwell Dictonary of Political Science, jest to grupa osób nadrzędna w stosunku do wspólnoty, charakteryzująca się wyższym statusem społecznym, wykształceniem (intellectual brilliance), mająca wyższy status majątkowy oraz władzę . W przypadku Chińskiej Republiki Ludowej

\footnotetext{
${ }^{1}$ Całość dokumentu patrz: Zhongguo de heping fanzhan daolu baipi shu, 22.12.2005, strona internetowa Wydziału Łączności Międzynarodowej Komitetu Centralnego Komunistycznej Partii Chin http://www.idcpc.org.cn/zhonggong/051222.htm (stan z 2.03.2006)

${ }^{2}$ Inaczej pojęcie elit przedstawione zostało w Stowniku wyrazów obcych W. Kopalińskiego: „Elita jest to grupa ludzi przodujących pod względem prestiżu, kwalifikacji a. władzy w danym środowisku, śmietanka, wybór, kwiat; zespół ludzi odgradzających się od ogółu w poczuciu swej rzeczywistej a. domniemanej wyższości pod jakimś względem”. Patrz: www.slownik-online.pl/kopalinski/c366cfd80956ff3ec12565bd0060c321.php (stan z 10.10.006).
} 
przez to pojęcie będziemy rozumieli zhongyang lingdao - centralne kierownictwo, lingdao hexin - główne kierownictwo oraz popularne w chińskich mediach określenie dang he guojia lingdaoren - przywódcy partyjni i państwowi ${ }^{3}$.

W obecnym kierownictwie do grupy elit zaliczamy członków Stałego Komitetu KC, oraz niewielką liczbę starszych rangą wojskowych z Chińskiej Armii Ludowo-Wyzwoleńczej. Zatem do ścisłego kierownictwa ChRL należy zaliczyć: Hu Jintao, Wu Bangguo, Wen Jiabao oraz Jia Qinglina i Zeng Qinghonga.

Dodatkowym elementem wskazującym na percepcję świata zewnętrznego przez elity jest ich kosmopolityzm, na który składają się: 1. wykształcenie zagraniczne; 2. znajomość języków obcych; 3. wizyty zagraniczne ${ }^{4}$. Spośród dziewięciu członków Stałego Komitetu Biura Politycznego Komitetu Centralnego tylko Luo Gan ukończył studia zagraniczne w Niemieckiej Republice Demokratycznej na Uniwersytecie Górnictwa i Technologii oraz kurs języka niemieckiego na Uniwersytecie Karola Marksa (tab. 1).

Tabela 1. „Kosmopolityzm” Stałego Komitetu Biura Politycznego KPCh (stan z 2006 r.)

\begin{tabular}{|l|c|c|c|}
\hline $\begin{array}{c}\text { Nazwisko } \\
\text { i imię }\end{array}$ & Pełniona funkcja & $\begin{array}{c}\text { Uniwersytet, wykształcenie, } \\
\text { data ukończenia studiów } \\
\text { (w tym zagranicznych) }\end{array}$ & $\begin{array}{c}\text { Znajomość } \\
\text { języków } \\
\text { obcych }\end{array}$ \\
\hline 1 & 2 & 3 & 4 \\
\hline Hu Jintao & $\begin{array}{c}\text { sekretarz KPCh, przewodniczący } \\
\text { państwa; przewodniczący Centralnej } \\
\text { Komisji Wojskowej }\end{array}$ & $\begin{array}{c}\text { Qinghua Daxue; inżynier } \\
\text { hydraulik; 1964; brak }\end{array}$ & brak \\
\hline $\begin{array}{l}\text { Wu } \\
\text { Bangguo }\end{array}$ & przewodniczący Stałego Komitetu & $\begin{array}{c}\text { Qinghua Daxue; Wydział } \\
\text { Radiowo- } \\
\text {-Elektroniczny; 1967; brak }\end{array}$ & brak \\
\hline $\begin{array}{l}\text { Wen } \\
\text { Jiabao }\end{array}$ & premier Rady Państwowej & $\begin{array}{c}\text { Pekiński Instytut Geologicz- } \\
\text { ny; geolog; 1968; brak }\end{array}$ & brak \\
\hline $\begin{array}{l}\text { Jia } \\
\text { Qinglin }\end{array}$ & przewodniczący Rady Polityczno- \\
Konsultatywnej & $\begin{array}{c}\text { College Mechaniczny w } \\
\text { Hebei; Wydział Energii } \\
\text { Elektrycznej; 1962; brak }\end{array}$ & brak \\
\hline $\begin{array}{l}\text { Zeng } \\
\text { Qinghong }\end{array}$ & WhRL; dyrektor Centralnej Szkoły \\
\hline Partyjnej & $\begin{array}{c}\text { Pekiński Instytut Technolo- } \\
\text { giczny; 1963; brak }\end{array}$ & brak \\
\hline Huang Ju & pierwszy wicepremier & $\begin{array}{c}\text { Qinghua Daxue; Wydział } \\
\text { Elektryczny; 1963; brak }\end{array}$ & brak \\
\hline
\end{tabular}

${ }^{3} \mathrm{C}$ h e n Mumin, Going Global: The Chinese Elite's Views of Security Strategy in the 1990's, „Asian Perspective” 2005, Vol. 29, No 2, s. 142.

${ }^{4}$ Podział ten został przyjęty w latach sześćdziesiątych XX w., kiedy liczba wizyt zagranicznych liderów ChRL była ograniczona. $\mathrm{Z}$ uwagi na zmiany ilościowe autor zdecydował o przedstawieniu tylko dwóch pierwszych wskaźników dla Stałego Komitetu KC KPCh. Szerzej patrz: R. A. S c a l a p i n o, The Transition in Chinese Party Leadership: A Comparison of the Eight and Ninth Central Committee, [w:] Elites in the People's Republic of China, red. R. A. Scalapino, University of Washington Press, Seatle 1972, s. 124. 
Tab. 1 (cd.)

\begin{tabular}{|l|c|c|c|}
\hline \multicolumn{1}{|c|}{1} & 2 & 3 & 4 \\
\hline $\begin{array}{l}\text { Wu Gu- } \\
\text { anzheng }\end{array}$ & $\begin{array}{c}\text { dyrektor Wydziału } \\
\text { Inspekcji KC (julu } \\
\text { diaocha) }\end{array}$ & $\begin{array}{c}\text { Qinghua Daxue; Wydział Energii Termalnej; } \\
\text { 1968; brak }\end{array}$ & brak \\
\hline $\begin{array}{l}\text { Li } \\
\text { chang- } \\
\text { chun }\end{array}$ & $\begin{array}{c}\text { Kompowiedzialny za } \\
\text { (jinsheng wenming } \\
\text { jianshe weiyuanhui) }\end{array}$ & $\begin{array}{c}\text { Instytut Technologiczny w Harbin; Wydział } \\
\text { Elektryczny; 1966; brak }\end{array}$ & brak \\
\hline Luo Gan & $\begin{array}{c}\text { sekretarz Komitetu ds. } \\
\text { Prawnych (legislacyj- } \\
\text { nych) }\end{array}$ & $\begin{array}{c}\text { Pekiński Instytut Żelaza i Stali; studia na } \\
\text { Uniwersytecie Górnictwa i Technologii we } \\
\text { Freibergu (NRD) - 8 lat; 1962; nauka języka } \\
\text { niemieckiego na Uniwersytecie Karola Marksa }\end{array}$ & niemiecki \\
\hline
\end{tabular}

Źródło: opracowanie własne na podstawie danych biograficznych ze stron internetowych Chińskiej Agencji Prasowej Xinhua

\section{Tradycyjne myślenie Chińczyków}

Na tworzenie się koncepcji państwa, a co za tym idzie polityki zagranicznej, niewatpliwy wpływ ma wykształcenie oparte na rodzimych i tradycyjnych wartościach. W tradycyjnej chińskiej myśli filozoficznej wyróżnia się dwa podstawowe systemy filozoficzne: konfucjanizm i taoizm. Konfucjańskie myślenia polityczne było linearne, hierarchiczne, tzn. wszyscy w społeczeństwie akceptowali pozycję władcy. Konfucjanizm zakładał również osiagnięcie jedności świata, wypływającej z jego koncepcji bipolarnej - spokoju i zakłopotania (he ping i luan), m.in. poprzez przedstawianie walczących królestw i wielkiej jedności (da tong) ${ }^{5}$. Dodatkowo w konfucjanizmie funkcjonowała idea „,działania bez nagrody" - człowiek wykonywał swoje obowiązki, traktując je jako moralnie słuszne, nie oczekując w zamian wynagrodzenia ${ }^{6}$. W zdecydowany sposób stanowi to o legitymizacji władzy, a w konsekwencji - przyzwolenie na rozwijanie własnych koncepcji ustrojowych. Przełożenie takiego myślenia na stosunki zagraniczne skutkuje chęcią podporządkowania innych, co w konsekwencji ma oznaczać harmonię i pokojowe współistnienie.

W dziełach taoistycznych z kolei zwracano uwagę przede wszystkim na sprzeczności (mao dun). Odnajdowano je przede wszystkim w koncepcji yin i yang, wzajemnie się zwalczających sił ciemności i światła, zła i dobra, kobiety i mężczyzny, które jednocześnie wzajemnie się uzupełniały. Laozi, ideologicznie anarchizujący, idealizował „nie mieszanie się” w sprawy świata oraz

${ }^{5}$ Szerzej patrz: W. O l s z e w s k i, Chiny. Zarys kultury, Wydawnictwo UAM, Poznań 2003, s. $58-60$.

${ }^{6}$ K. G a w li k ow s k i, Nowa batalia o Konfucjusza, Wydawnictwo MON, Warszawa 1975, s. 13-16; Dialogi konfucjańskie, przeł. K. Czyżewska-Madajewicz, M. J. Künstler, Z. Tłumski, Ossolineum, Warszawa 1976; F e n Y o u l a n g, Krótka historia filozofii chińskiej, Wydawnictwo MON, Warszawa 2001, s. 50-51oraz B. S c h w a r t z, Some Polarities in Confucian Thought, [w:] Confucianism and Chinese Civilazation, red. A. F. Wright, Stanford University Press, Stanford 1975. 
proponował nie branie udziału i wycofanie się z działań (wu-wei). W filozofii taoistycznej wyrażało się to w słowach: „Im więcej na świecie będzie zakazów, w tym głębszej nędzy ludzie żyć będą"7. Jednak droga (dao), mimo że nie działała, to jednak była przyczyną wszystkiego, co otaczało ludzi. Według taoistów, władca powinien realizować wzorzec dao - niczego nie czynić i pozwolić podwładnym, by czynili to, co mogą sami robić. ${ }^{8}$ Teoria niedziałania stała się z czasem jedną z podstaw szkoły legistów (fajia), na której wzorował się przewodniczący Mao Zedong. W traktacie Shangjunshu (Ksiega księcia Shanga) Shan Yang uznawał za dwie podstawy siły państwa rolnictwo i armię, odrzucając handel oraz konfucjańskie nauczanie literatury ${ }^{9}$. Założenia legistów postulowały umacnianie państwa, panującej dynastii oraz armii. Wobec stanowionego prawa wszyscy mieli być równi, a władca zachowywał dla siebie nagradzanie bądź karanie podwładnych ${ }^{10}$. Zjednoczenie państwa miało następować nie jak w konfucjanizmie na drodze moralnego przykładu władzy, lecz na drodze siłowej, z użyciem armii wspierającej państwo despotyczne ${ }^{11}$.

Najważniejszym elementem był jednak pierwiastek $q i$ - duch wszechświata, mentalny fenomen wszystkich Chińczyków ${ }^{12}$. Pierwiastek ten idealizował postawę przewodniczącego Mao Zedonga: „Mówię, idea staje się rzeczywistością, limit jest bezgraniczny, zasada czasu jest potężna, wyobraźnia staje się myślą, forma nabiera znaczenia. Jestem wszechświatem - małym, ale wielkim" ${ }^{\prime 13}$.

Oprócz aspektów czysto filozoficznych duży wpływ na wizję świata mają przede wszystkim chińskie utwory literackie, a także lektura pism chińskich strategów m.in. wizja Sun $\mathrm{Zi}$, Romans Trzech Królestw (San Guo Yanyi) Luo Guanzhona ${ }^{14}$ i Opowieści znad Brzegu Rzeki (Shui hu zhuang)

${ }^{7}$ F e n g Y o u l a n g, Krótka historia filozofii chińskiej, PWN, Warszawa 2001, s. 118.

${ }^{8}$ Ibidem, s. 119.

${ }^{9}$ M. S. Z i ę b a, Chińska filozofia, [w:] Powszechna encyklopedia filozofii, Katolicki Uniwersytet Lubelski, www.kul.lublin.pl/efk/pdf/c/chinskafilozofia.pdf.

${ }^{10} \mathrm{O}$ różnicach między szkołami legistów, daoistów oraz konfucjanistów szerzej patrz: F e n Y o u 1 a n g, op. cit., s. 185-187. Por. również K. G a w 1 i k o w s k i, Ideologia KPCh a klasyczna filozofia chińska. Przyczyny zywotnosci klasycznej filozofii chinskiej, „Studia Filozoficzne” 1973, nr 3, s. 25-45 oraz F. B y k o w, Powstanie chińskiej myśli politycznej i filozoficznej, Wydawnictwo MON, Warszawa 1978, s. 104-105.

${ }^{11}$ K. G a w 1 i k o w s k i, op. cit., s. 44-45.

${ }^{12}$ Chiński ideogram $q i$ - składa się ze znaku reprezentującego gotowany ryż oraz znaku oznaczającego parę wodną, co wskazuje na podwójną, materialną i niematerialną, naturę qi. Dosłownie pojęcie to oznacza 'gaz' lub 'oddech'. W filozofii chińskiej termin ten używany jest na określenie jednocześnie ,życiowego tchnienia” i „kosmicznej energii”. Jest to więc chińska odmiana idei fundamentalnej jedności człowieka i wszechświata. $Q i$ oznacza także 'intencje', 'emocje', co obrazuje potoczny zwrot shengqi - 'złościć się', który oznacza dosłownie 'rodzić', albo 'wydawać na świat qi'. Patrz: L a m L a i S in g, Mao Tse-tung's Purposive contention with the Superpowers, The Theory of Ch'i, Lewiston, Queenstone, Lampeter 1995, s. 7-9.

${ }^{13}$ Ibidem.

${ }^{14}$ San Guo Yanyi - dzieło literackie z XV w. czyli przełomy dynastii Ming i Qing, przypisywane jest autorowi znanemu jako Luo Guanzhong. Główny jego wątek stanowi historia walczą- 
Shi Naiana ${ }^{15}$. Niewątpliwie najważniejsza zasadą Mistrza Sun było twierdzenie, że „wojna to sztuka wprowadzania w błąd”. Znalazło ono swoje odzwierciedlenie w tekście $O$ przewlektej wojnie:

Nie będziemy naśladować Xianggonga, władcy królestwa Song, niepotrzebna nam jest jego głupia rycerskość. Powinniśmy w jak najgruntowniejszy sposób zalepić nieprzyjacielowi oczy i uszy, by był ślepy i głuchy. Powinniśmy jak najbardziej dezorientować jego dowódców, aby całkowicie potracili głowy, i wyzyskać to do osiagnnięcia zwycięstwa ${ }^{16}$.

Starożytny mistrz zalecał przede wszystkim dezinformację przeciwnika oraz działanie bez względu na możliwości państwa. Umiejętne prowadzenie wojny miało polegać na unikaniu otwartej walki, podstawą było zniszczenie strategii przeciwnika, rozbicie jego sojuszów, a dopiero na trzecim miejscu - jego $\operatorname{armii}^{17}$.

Z kolei w Romansie Trzech Królestw świat został przedstawiony w układzie tripolarnym (san fen tian xia), co dawało podstawy do tworzenia koncepcji trójstronnych - potrójnego sojuszu w polityce wewnętrznej, trzech światów i postrzegania świata w relacjach Chiny i dwa supermocarstwa ${ }^{18}$. W opowiadaniu tym wszystkie konflikty zbrojne kończyły się klęską strony atakującej. Zatem nasuwają się konkretne wnioski. Po pierwsze, tendencje defensywne dawały większe korzyści, po drugie zaś dla osiagnięcia zwycięstwa należało stworzyć wielostronny zjednoczony front. Takie tendencje niewątpliwie można odnaleźć w dyplomacji Chińskiej Republiki Ludowej we współczesnych czasach.

Rozważania te prowadziły przede wszystkim do zdefiniowania pojęcia wroga, roli człowieka w tworzeniu historii, a także elementów taktyki i prowadzenia polityki. Ponadto późniejsze podejście do stosunków międzypaństwowych warunkowane było przez fakt, że ,prawem historii jest, że silny może pokonać słabego, słaby może pokonać silnego", zatem biedny może pokonać bogatego, a słabo uzbrojony - potężne mocarstwo. Teoria ta była zaprzeczeniem poglądów

cych królestw Wei, Wu i Shu oraz próby przejęcia władzy przez kolejnych przywódców wymienionych państw. Bohaterem opowieści są stratedzy Zhuge Liang, Zhang Fei oraz półbóg Guan Yu. Patrz: Chinese Literature www.chinaknowledge.de/Literature/Novels/sanguoyanyi.html.

${ }^{15}$ Shui hu zhuan - dzieło literackie z XIV w., napisanie pod koniec dynastii Yuan i na początku dynastii Ming, omawijące rolę powstań chłopskich. Prawdopodobnym autorem był Shi Naian. Patrz: http://www.chinaknowledge.de/Literature/Novels/shuihuzhuan.html oraz G. T a n En g B o k, Strategic Doctrine, [w:] Chinese Defence Policy, ed. G. Segal, W. T. Tow, Urbana and Chicago 1984, s. 5.

${ }^{16} \mathrm{M}$ a o Z Z d o n g, O przewlektej wojnie..., s. 238.

${ }^{17}$ Por. S u n T s u, Art of War, przeł. R. D. Sawyer, Boulder 1994, s. 171-180; S u n Z i, Sztuka wojenna, przeł. R. Stiller, Warszawa 2003, s. 21, 36-37 oraz K. Gaw li k ow s k i, Klasyczna chińska literatura strategiczna i wojskowa, Warszawa 2002, s. 36-46.

${ }^{18} \mathrm{~W}$ rozdz. 38 Chu Ke przedstawił obraz świata tripolarnego z epoki walczących trzech królestw. Patrz: Romans Trzech Królestw, www.mypcera.com/book/gu/4/sgyy/038.htm. 
Mencjusza, a wsparta tezami legistów oraz konfucjańskim pojęciem niemożliwej kapitulacji dawała szansę nieograniczonego rządzenia państwem ${ }^{19}$.

Tradycyjne koncepcje podejścia Chińczyków do świata zewnętrznego to pokojowa współpraca pod kopuła niebios (tian xia he yi) lub mająca podobną wymowę zgodność pod kopułą niebios (tian xia tong yi) ${ }^{20}$. Niewątpliwie wymownym przykładem takich koncepcji był chiński żeglarz Zheng He, który ponoć 70 lat przed Kolumbem dopłynął do Ameryki ${ }^{21}$. Mając przewage militarną nie rabował, lecz przesyłał pozdrowienia i podarki od cesarza Państwa Środka, podkreślając tym samym rolę własnej ojczyzny. Pokojową współpracę akcentował również podczas negocjacji z Indiami w 1953 r. premier ChRL, Zhou Enlai. Jego koncepcja przeszła do historii dyplomacji jako pięciopunktowy plan pokojowego współistnienia z konferencji w Bandungu z 1955 r. (heping gongchu).

Należy ponadto podkreślić, że w całej historii Chin niewielu jest zdobywców i konkwistadorów, a do takich należy zaliczyć cesarza Wu Di, który - mimo adaptacji konfucjańskiego modelu władzy - dokonał podboju licznych ziem sąsiadujących z Chinami czy też Zheng Chenggonga, który w 1661 r. odbił z rąk Holendrów Tajwan, a jego wielki posag stoi dziś na nabrzeżu w Xiamen (prowincja Fujian). Zatem nie zawsze Chińczycy byli ,pokojowo nastawieni do świata zewnętrznego". Z reguły zależało to od możliwość i siły Państwa Środka, nie zaś od wyznawanej filozofii. Wystarczy przypomnieć tylko takie idee, jak Chiny środkiem świata (Zhong yang zhi guo) czy też koncepcję składania trybutu przez państwa sąsiednie (feng gong guanxi). Wedle chińskiej tradycji stabilizacja w regionie miała być osiagnięta nie tyle dzięki równowadze sił, jak było to w cywilizacji zachodniej, ile dzięki dominacji stabilnego Państwa Środka ${ }^{22}$.

\section{Rewolucja - modernizacja - nowe koncepcje}

Postrzeganie świata zewnętrznego należy łączyć z tworzeniem nowoczesnego państwa - Nowych Chin. W konsekwencji zmian ideologicznych

\footnotetext{
${ }^{19}$ Por. Fe n g Y o u la n, op. cit., s. 84-87.

${ }^{20}$ Tradycyjne koncepcje podejścia Chińczyków do świata zewnętrznego, takie jak: pokojowa współpraca pod kopułą niebios (tian xia he yi), czy też mająca podobną wymowę koncepcja zgodności pod kopułą niebios (tian xia tong yi), Chiny jako środek świata (Zhong yang zhi guo) czy też koncepcje składania trybutu przez państwa sąsiednie (feng gong guanxi). Por. J i a ng $\mathrm{X}$ i y u a n, X i a Li p ing, Zhongguo heping jueqi [Pokojowe wzrastanie Chin - wszystkie tłumaczenia z języka chińska zostały sporządzone przez autora], Beijing 2003, s. 139-141 oraz R. H. S o 1 o m o n, A Revolution is not a Dinner Party, with the collaboration of T. W. Huey, New York 1975, s. 122-123.

${ }^{21}$ Szerzej patrz: G. M e n zi e s, 1421 rok w którym Chińczycy odkryli Ameryke $i$ optynęli świat, Amber, Warszawa 2002.

${ }^{22}$ J. K. F a i r bank, The Chinese World Order: Traditional China's Foreign Relations, Cambridge University Press, Cambridge 1968, s. 10.
} 
(a następnie strukturalnych) dochodziło do zmiany percepcji otaczającego świata. W tym aspekcie należy dokonać rozróżnienia na dwa okresy: 1. rewolucyjny (do 1976 r.); 2. modernizacji państwa (po 1978 r.), która trwa do dziś.

W pierwszym okresie to budowanie rewolucyjnego modelu państwa determinowało postrzeganie świata zewnętrznego. Oceniając sytuację międzynarodową Mao Zedong twierdził, że istniały dwie możliwości: „albo rewolucja światowa zapobiegnie wojnie, albo wojna globalna zrodzi rewolucję" ${ }^{\text {"23 }}$. Charakteryzował te zagadnienia w następujący sposób:

Wiadomo, że wojna i pokój to zjawiska, z których jedno przekształca się w drugie. Na miejsce wojny przychodzi pokój [...]. Na miejsce pokoju przychodzi wojna [...]. Dlaczego tak się dzieje? Dlatego, że w społeczeństwie klasowym takie sprzeczne zjawiska jak wojna i pokój są w określonych warunkach związane wzajemnie ${ }^{24}$.

Założenia determinizmu historycznego wskazywały na ostateczne „położenie kresu wojnie”. Miało to jednak nastapić poprzez „zwalczanie wojny wojną”: wojną rewolucyjną - wojny kontrrewolucyjnej, rewolucyjną wojną narodową kontrrewolucyjnej wojny narodowej, rewolucyjną wojną klasową - kontrrewolucyjnej wojny klasowej ${ }^{25}$. Taka konstrukcja filozoficzna przygotowywała grunt pod wybuch konfliktu zbrojnego.

Ważnym aspektem prowadzonej wojny był czynnik jednoczący społeczeństwo, a to warunkowało przeprowadzenie rewolucji. Komunistyczna Partia Chin wykorzystała II wojnę światową, tworząc niezależne państwo. Kolejna wojna miała przynieść uciskanym narodom świata wyzwolenie ${ }^{26}$.

Podstawowym zadaniem służącym pokonaniu wrogów - imperializmu i socjalimperializmu, podobnie jak w walce wewnątrzpartyjnej - było wielkie zjednoczenie państw trzeciego świata. Podłożem dla zjednoczenia wszystkich państw Azji, Afryki i Ameryki Łacińskiej miały być, według Mao, wspólne doświadczenia walki z imperializmem oraz podobny stopień rozwoju politycz-

${ }^{23} \mathrm{M}$ a o Z Z dong, Shijie dazhang de liang zhong kenengxing [Dwie możliwości wojny światowej], [w:] Mao Zedong waijiao..., s. 470-471.

${ }^{24} \mathrm{M}$ a o Z e d on g, W sprawie sprzeczności, [w:] i d e m, Dzieła wybrane, t. 2, Warszawa 1955, s. 369. Krytyka ze strony radzieckiej patrz.: List otwarty Komitetu Centralnego Komunistycznej Partii Zwiazku Radzieckiego. Do organizacji partyjnych, do wszystkich komunistów Zwiazku Radzieckiego, Wydanie specjalne tygodnika „Kraj Rad”, bdw, s. 9-16.

${ }^{25} \mathrm{M}$ a o Z e d o n g, Zagadnienia wojny rewolucyjnej w Chinach, grudzień 1936, [w:] Wybrane pisma wojskowe Mao Zedonga, Warszawa 1960, s. 105-106.

${ }^{26} \mathrm{M}$ a o Z e d o ng, Women yinggai gongtong nuli lai fangzhi zhanzheng, zhengqu chijiu heping [Powinniśmy czynnić wiele wysiłków stawiając opór wojnie, długo utrzymywać pokój], 23.10.1954, [w:] Mao Zedong waijiao..., s. 168-173 oraz i d e m, Shijie de quantu shi guanming de, daolu shi quzhe de [Światowa droga ma świetlaną przyszłość, droga jest zygzakiem], 17.10.1945, [w:] ibidem, s. 53-54. 
nego, społecznego oraz gospodarczego ${ }^{27}$. Ewentualność konfliktu zbrojnego z imperializmem amerykańskim dawała możliwość zjednoczenia państw azjatyckich, afrykańskich, europejskich i Ameryki Łacińskiej, a w konsekwencji dogodną sytuację dla rozwoju rewolucji ${ }^{28}$.

Chiny na arenie międzynarodowej miały się zjednoczyć ze wszystkimi państwami w celu osiagnnięcia wielkich sukcesów: „Dopóki trwa imperializm, dopóty należy być zjednoczonym i trwać w walce aż do końca"29. Zjednoczenie było warunkowane powstaniem partii komunistycznej, aby nie powtórzył się scenariusz z 1911 r., kiedy obalenie cesarstwa nie doprowadziło do rewolucji ${ }^{30}$. Trwanie zatem $\mathrm{w}$ postawie rewolucyjnej stanowiło o sile Chin (fuqiang) ${ }^{31}$. Założenie determinizmu historycznego ${ }^{32}$ wskazywało, że walka klasowa będzie trwała aż do ostatecznego zwycięstwa komunizmu, dlatego potrzeba utworzenia zjednoczonego frontu była tak ogromna. Miało to nastąpić w latach sześćdziesiątych XX w., w okresie dominacji myśli Marksa, Lenina i Mao Zedonga, a „czas imperializmu i rewizjonizmu kończył się" (yue lai yue bu hao guo) ${ }^{33}$.

W przeciwieństwie do realizowanych koncepcji pokojowej współpracy, idee Mao Zedonga miały prowadzić do wzniecenia rewolucji. Pokojowe koncepcje polityki zagranicznej zostały sformułowane w liście Wang Jiaxianga do Zhou Enlaia, Deng Xiaopinga oraz Chen Yi z dnia 27 lutego 1963 r. Główne postulaty koncentrowały się wokół pokojowej polityki wobec Związku Radzieckiego i Stanów Zjednoczonych, nie uwzględniającej różnic systemów politycznych tych państw, a także stopniowego ograniczania możliwości wybuchu

${ }^{27}$ Ma o Zedong, Diguozhuyi shi bu kepa de [Nie obawiamy się imperializmu], 7.05.1960, [w:] Mao Zedong waijiao..., s. 403-412 oraz m.in. A United Front Against U.S. Imperialism and Soviet Revisionism must be Established, „Peking Review” 1969, nr 31, s. 22-23.

${ }^{28}$ Y e Z i c h e ng, Xin Zhongguo Waijiao Sixiang: Cong Mao Zedong dao Deng Xiaoping, Mao Zedong, Zhou Enlai, Deng Xiaoping Waijiao Sixiang Bijiao Yenjiu, Beijing 2001, s. 83.

${ }^{29} \mathrm{M}$ a o Z e d o n g, Yizhi dadao Mei diguozhuyi yuanyi bashou weizhi, 7.02.1953, [w:] Mao Zedong waijiao..., s. 156.

${ }^{30} \mathrm{~W}$ wyniku rewolucji, na której czele stanął dr Sun Jat-sen, pozbawiono władzy dynastię mandżurską Qing. Jednak mimo starań nie udało się stworzyć dobrze funkcjonującego państwa republiki. Doprowadziło to do walk wewnętrznych między warlordami (militarystami). Nowy republikański rząd nie wszedł nawet w fazę organizacyjną. W wyniku toczonych walk Yuan Shikai ogłosił się cesarzem Chin. Szerzej patrz: P. B. E ble y, op. cit., s. 266-267 oraz J. D. S p e n c e, The Search for Modern China, New York-London 1991, s. 275-281.

${ }^{31} \mathrm{M}$ a o Zedong, Zhongguo he waijiao de guanxi [Stosunki Chin $\mathrm{z}$ zagranica], 25.04.1956, ibidem, s. 235-239.

${ }^{32}$ Determinizm jest to pogląd, zgodnie z którym zajście każdego zdarzenia jest wyznaczone jednoznacznie przez zdarzenia poprzedzające je w czasie. Determinizm historyczny natomiast zakłada, że dzieje podlegają ściśle określonym prawom - formacje społeczne zmieniają się w wyniku rozwoju środków produkcji i stosunków społecznych. Por. Encyklopedia PWN, www.encyklopedia.pwn.pl/16569_1.html.

${ }^{33}$ Yong Mao Zedong sixiang tongshi yiqie [Stosując idee Mao Zedonga pokonamy wszystko], ,Hongqi” 1969, nr 1, s. 11. 
konfliktu zbrojnego ${ }^{34}$. Taka linia została określona mianem „trzech pokojów i jednego zmniejszania" (san he yi shao), czyli pokojowych rozmów z przedstawicielami imperializmu (diguo zhuyi), współczesnego rewizjonizmu (xiandai xiuzheng zhuyi) i frakcjonizmu (fan dong pai), a także zakładał zmniejszanie pomocy dla walczących w wojnach narodowo-wyzwoleńczych (ge guo renmin geming touzheng) ${ }^{35}$. W opinii przewodniczącego, całą politykę międzynarodową należało oprzeć na zasadzie „trzech otoczeń i jednego podsycania” (san jiang yi mie). Taka koncepcja prowadziła do próby okrążenia imperializmu, współczesnego rewizjonizmu, a także frakcjonalizmu oraz wzniecania wojen rewolucyjnych $^{36}$.

Polityka otwarcia na świat i tworzenie specjalnych stref ekonomicznych nie odpowiadały rewolucyjnym formom z minionej epoki (1966-1976). Reformy Deng Xiaopinga doprowadziły do dyskusji na temat percepcji świata zewnętrznego przez Komunistyczną Partię Chin. Preferowano wówczas powrót do koncepcji z lat pięćdziesiątych. Jednym z wyróżników działań premiera na arenie międzynarodowej było promowanie rozwiązań pokojowych. Pełniąc obowiązki ministra spraw zagranicznych (do 1958 r.) przedstawił 31 grudnia 1953 r. pięć zasad pokojowego współistnienia podczas negocjacji z Indiami: poszanowania integralności terytorialnej państwa (huxiang zengzhong linshi zhuquan), wzajemnej nieagresji (hubu qinfan), nie ingerowania w sprawy wewnętrzne (hu bu ganbu neizhang), równych korzyści (pingdeng hu hu) oraz pokojowego wspótistnienia (heping gongchu) ${ }^{37}$. Mimo dopuszczalnych konsultacji ze Stanami Zjednoczonymi i Japonią premier stawiał konkretne warunki negocjacji i współpracy. Przede wszystkim rozmowy nie mogły przebiegać we wrogiej atmosferze (dui shou, dishi). Państwa przystępujące do rozmów z Chinami miały zapewniać o integralności terytorialnej ChRL, w tym integralności z Tajwanem, a także promować wymianę w stosunkach bilateralnych ${ }^{38}$.

$\mathrm{Na}$ początku lat osiemdziesiątych ubiegłego wieku przed chińskimi elitami stanęły trzy poważne problemy: powstrzymywanie hegemonii ZSRR; ochrona światowego pokoju, służąca zmianom wewnętrznym w Chinach oraz reunifika-

${ }^{34}$ Li J i e, Mao Zedong yu Xin Zhongguo de Neizheng Waijiao [Mao Zedong i wewnętrzne uwarunkowania dyplomacji Nowych Chin], Beijing 2003, s. 206-207.

${ }^{35} \mathrm{M}$ a o $\mathrm{Z}$ e d o n g, Bixi zhicai fandongpai [Musimy zniszczyć grupy reakcyjne], 1.08.1939, www.maostudy.org/archive/zhuzuo/mzdmain.php3?article=mxj2/mxj2016.txt (stan z 16.10.2006).

${ }^{36}$ Xuexi ziliao...

${ }^{37} \mathrm{M}$ a o $\mathrm{Z}$ e d o $\mathrm{n}$ g, Heping gongchu wu xiang yuance [Pięć zasad pokojowego współistnienia], [w:] Mao Zedong waijiao..., s. 63 oraz J. R e s t o n, Interview with Zhou Enlai, August 5, 1971, from The New York Times August 10, 1971, [w:] People's China, Social Experimentation, Politics, Entry onto the World Scene 1966 through 1972..., s. 497-501.

${ }^{38} \mathrm{Zh}$ ou Enlai, Guanyi zujing Zhong Ri guanxi de zhengzhi san yuanze he maoyi san yuanze [O trzech zasadach w stosunkach politycznych i handlowych między Chinami i Japonia], 27.08.1960, ibidem, s. 289-290. 
cja z Tajwanem. Nowa strategia została przedstawiona w formie 7 punktów: dogłębnej analizy (leng jing guan cha); utrzymywania pozycji (wen zhu zhen jiao); budowy zaufania (chen zhe ying fu); ukrywania własnych możliwości (tao guang yang hui); utrzymywania niskiego poziomu (shan yu shou zhuo); nie bycia liderem (jue bu dang tou) oraz osiagania pewnych korzyści (you suo zuo wei).

Ponadto horyzontalne reformy dały impuls do rozwijania bardziej logicznych kontaktów władz lokalnych z partnerami zagranicznymi, co otworzyło drogę szybszej wymiany i gotowości na przyjęcie zagranicznego kapitału. Najlepszą ilustracją tego procesu były w miarę niezależne posunięcia takich prowincji, jak: Zhejiang, Fujian, Guangdong czy Szanghaj, dzęki którym na poziomie prowincjonalnym utworzono biura współpracy z zagranicą ${ }^{39}$. Przykładem potwierdzające szersze kompetencje władz lokalnych w zakresie relacji z zagranicą były m.in. wizyty sekretarza KPCh w Suzhou, Wang Ronga, oraz wicegubernatora prowincji Zhejiang, Zhong Shana, w Singapurze ${ }^{40}$. Ponadto coraz większa rolę $w$ stosunkach zagranicznych odgrywały regionalne biura handlu zagranicznego, takie jak np. Biuro ds. Współpracy Handlowej i Ekonomicznej z Zagranicą Prowincji Zhejiang ${ }^{41}$.

Ważnym elementem zapewniającym stabilizację wewnętrzną jest budowa zamożnego społeczeństwa (xiao kang shehui) oraz zwiększanie poziomu edukacji i wykształcenia, realizowane przez gabinet Wen Jiabao w ramach programu Kejiao Xing Shi ${ }^{42}$. Budowa „społeczeństwa zamożnego” została oficjalnie przyjęta na XVI Zjeździe Komunistycznej Partii Chin w listopadzie 2002 r. Zgodnie z planami KPCh do 2020 r. średnie zarobki w całych Chinach maja wynosić ok. 3000 USD per capita ${ }^{43}$. Dla tak sugerowanych planów ChRL potrzebuje stabilnego środowiska międzynarodowego, dającego możliwości wymiany handlowej i gospodarczej. Drugim elementem racjonalnie uzasadniajacym chęć współpracy międzynarodowej są programy pomocowe, które w dalszym ciągu są kierowane do Państwa Środka. Niewiele ponad $40 \%$ społeczeństwa chińskiego obejmuje opieka medyczna, co powoduje wzrost zagrożenia epidemiami i chorobami cywilizacyjnymi. Podjęto programy otwarcia na Zachód (dui xibu kaifang) oraz „naprawy” rolnictwa (san nong). Oprócz „społeczeństwa zamożnego” władze Chin przygotowują budowę „społeczeństwa

\footnotetext{
${ }^{39}$ Patrz: Shanghai People's Gov., www.shanghai.gov.cn oraz Department of Foreign Affairs Provincial Government of Zhejiang, www.zjswb.gov.cn.

${ }^{40}$ Foreign Ministry of Singapore, www.mfa.gov.sg/internet/foreignpolicy/nea_prc.htm.

${ }^{41}$ Zhejiang Foreign Trade and Economic Cooperation Bureau strona internetowa www. zftec.gov.cn

${ }^{42}$ Keshi shi di yi shengchang li, rencai shi di yi ziyuan [Technologia to siła przemysłu, zasoby ludzkie są najważniejsze], „Dongfang Zaobao”, 15.01.2004.

${ }^{43} \mathrm{~S}$ u G u o, Xiaokang shehui [Społeczeństwo zamożne], Sichuan 2003, s. 54-55.
} 
harmonijnego" (hexie shehui), a jest to skorelowane z budowaniem „pokojowej pozycji Chin w harmonijnym świecie stosunków międzynarodowych" (hexie shijie). Zatem czynnik postrzegania świata zewnętrznego przez pryzmat zmian wewnętrznych, choć nie jedyny, wydaje się kluczowy i to nie tylko w ciagu ostatnich 20 lat, lecz od początku istnienia Chińskiej Republiki Ludowej.

\section{Zachodnie koncepcje postrzegania świata}

Percepcja świata zewnętrznego przez chińskie elity jest widziana przez pryzmat zachodnich form wyjaśniających świat stosunków międzynarodowych: realizmu bądź liberalizmu ${ }^{44}$. Takie przedstawiane stosunków międzynarodowych znajduje odzwierciedlenie w układzie chińskich podręczników do spraw międzynarodowych ${ }^{45}$. Tylko $\mathrm{w}$ trzech spośród ośmiu przedstawiono tradycyjne chińskie wartości, takie jak pokojowe współistnienie, w pięciu zachodnie koncepcje postrzegania świata zewnętrznego, a w sześciu - opis sytuacji międzynarodowej (por. tab. 2).

Ponadto o tak formułowanej tezie dobitnie świadczą przykłady chińskich naukowców, w tym m.in. prof. Zhang Ruizhuang z Nankai University, który krytykował popierających heping yu fazhang - pokój i rozwój - przedstawiając teorię strukturalnego realizmu Kennetha Waltza. Realistyczne podejście do stosunków międzynarodowych wiąże się również z emanacją i podkreślaniem krzywd wyrządzonych Chińczykom przez mocarstwa zachodnie, przede wszystkim w XIX stuleciu. Tworzy to również podstawy dla chińskiego patriotyzmu - aiguo zhuyi. Najlepszym przykładem konstatacji układu międzynarodowego stała się opublikowana w 1996 r. praca Song Qianga, Zhang Cangcanga i Qian Biao, zatytułowana Zhongguo keyi skuo bu (Chiny moga powiedzieć nie $)^{46}$. Taka postawa nie jest wyjątkiem, podobne sugestie bowiem przedstawił profesor Beijing Normal University, Fang Ning, który uznał, że mocarstwa zachodnie od zawsze wykorzystywały Chiny, a w tej sytuacji muszą one rewita-

\footnotetext{
${ }^{44}$ Według Williama Towa, chińska percepcja świata zachodniego jest w dużej części warunkowana przez wpływ równowagi sił, który kształtowany był w okresie zimnej wojny między USA a ZSRR. Z drugiej strony m.in. Geral Segal twierdzi, że im bardziej Chiny będą powiązane ze światową ekonomią/gospodarką, tym mniej będą postrzegać świat przez pryzmat nacjonalistyczny. Por. Ch a o M u mi n, op. cit., s. 152.

${ }^{45} \mathrm{~W}$ badaniach podręczników rozróżniono następujące kategorie: 1 . chińskie wartości w postrzeganiu świata zewnętrznego; 2. marksistowskie ujęcia świata zewnętrznego; 3. koncepcje Deng Xiaopinga wobec świata zewnętrznego; 4. zachodnie koncepcje percepcji świata zewnętrznego; 5. opis sytuacji międzynarodowej po zakończeniu zimnej wojny.

${ }^{46}$ Zhongguo keyi shuo bu - lang zhan hou shidao de zhengzhi yu qinggan jueze [Chiny moga powiedzieć nie - wybór polityczny i emocjonalny w epoce po zimnej wojnie], Zhonghua Gongshan Lianhe Chubanshe, Beijing 1996, s. 435.
} 


\begin{tabular}{|c|c|c|c|c|}
\hline 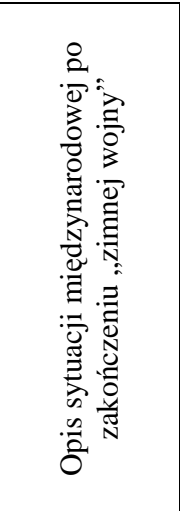 & 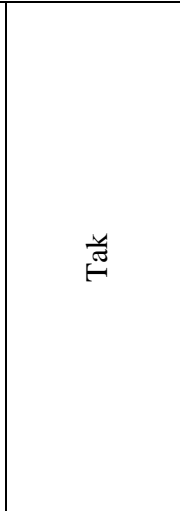 & 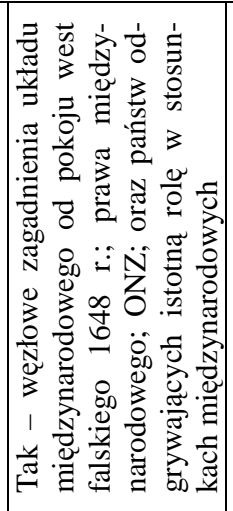 & 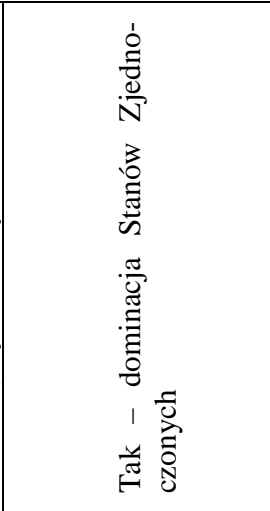 & 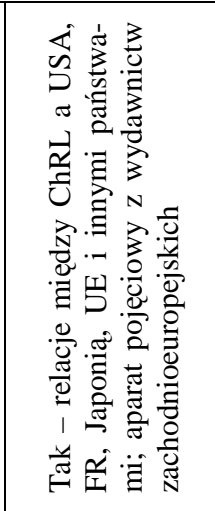 \\
\hline 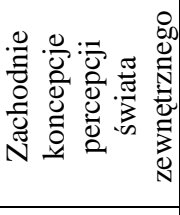 & 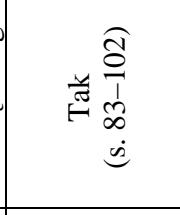 & $\stackrel{0}{z}$ & $\ddot{z}$ & $\stackrel{0}{\bar{z}}$ \\
\hline 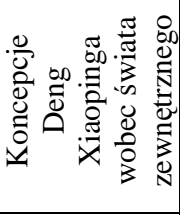 & 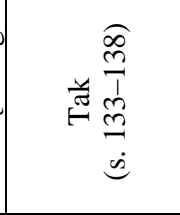 & : & $\ddot{z}$ & $\stackrel{0}{z}$ \\
\hline 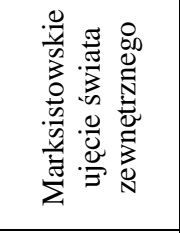 & 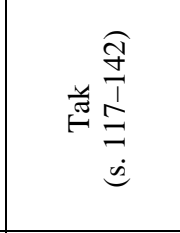 & $\stackrel{0}{z}$ & $\check{z}$ & $\stackrel{\check{z}}{\mathrm{z}}$ \\
\hline 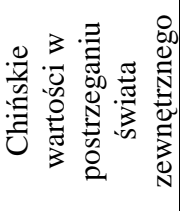 & 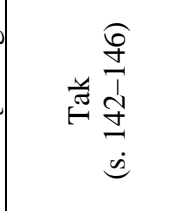 & 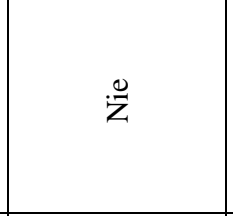 & 泫 & $\ddot{z}$ \\
\hline 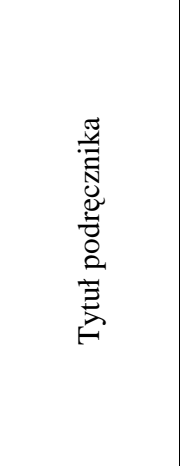 & 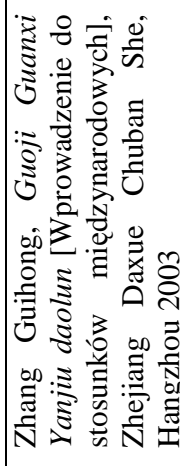 & 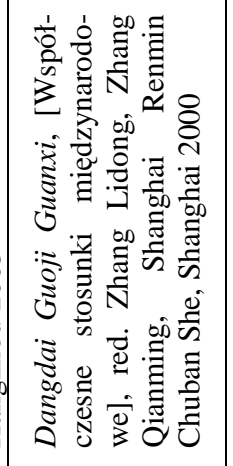 & 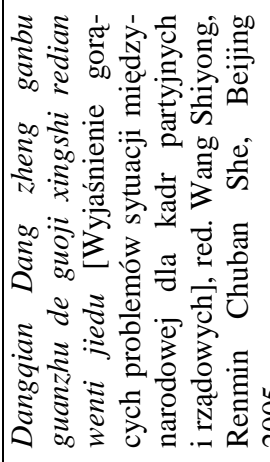 & 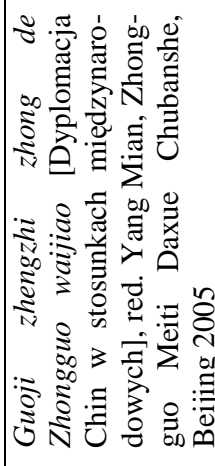 \\
\hline
\end{tabular}




\begin{tabular}{|c|c|c|c|}
\hline$\stackrel{0}{z}$ & $\stackrel{\oplus}{Z}$ & $\stackrel{\oplus}{z}$ & 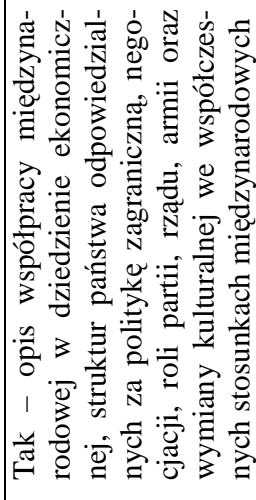 \\
\hline 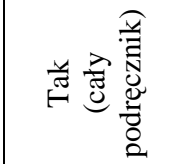 & 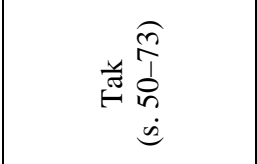 & 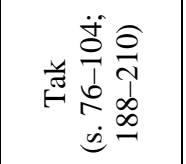 & 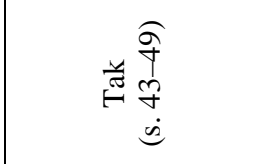 \\
\hline$\stackrel{0}{z}$ & 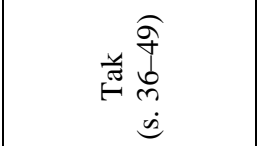 & $=\frac{\widehat{n}}{\stackrel{n}{1}}$ & 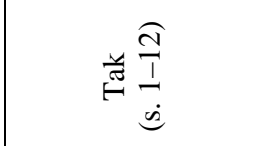 \\
\hline$\stackrel{0}{z}$ & 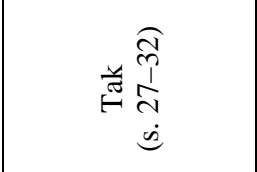 & 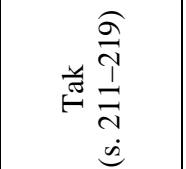 & $\stackrel{0}{z}$ \\
\hline 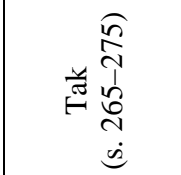 & $\stackrel{0}{Z}$ & $\stackrel{0}{z}$ & 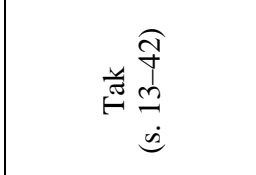 \\
\hline 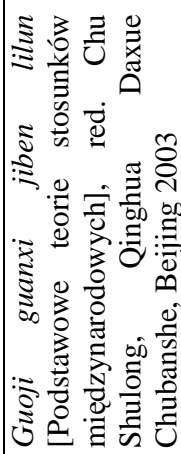 & 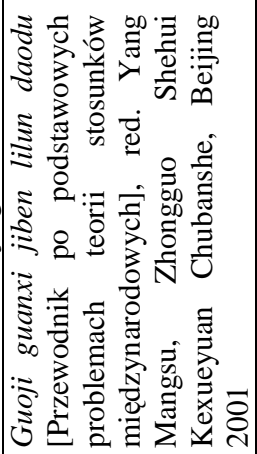 & 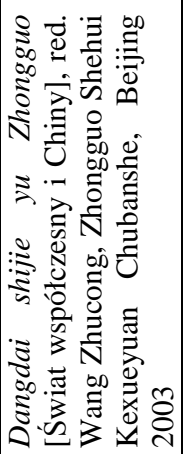 & 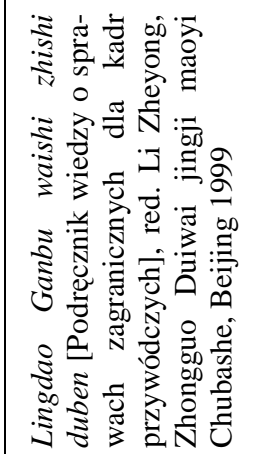 \\
\hline
\end{tabular}


lizować patriotyzm i nacjonalizm, przygotowując się do konfliktu ze światem zachodnim $^{47}$.

Druga grupa to zwolennicy koncepcji liberalnych - głównie biurokracja i ekonomiści - którzy uważaja że Chiny nie powinny dążyć do zmian układu, a tylko czerpać z niego korzyści (seize the opportunity). Elity te postrzegaja współczesne teorie ekonomiczne jako szansę dla Chin i opowiadają się za dalszą absorpcją kapitału zagranicznego (taki pogląd prezentuje m.in. profesor He Fang z CASS i Instytutu Stosunków Międzynarodowych przy Radzie Państwowej) ${ }^{48}$.

Tabela 3. Percepcja świata zewnętrznego przez chińskie elity

\begin{tabular}{|c|c|c|}
\hline & Negatywne & Pozytywne \\
\hline Grupa elit & $\begin{array}{l}\text { - realiści } \\
\text { - wojskowi } \\
\text { - stratedzy z ChAL-W } \\
\text { - MSZ } \\
\text { - konserwatywnie nastawieni intelektua- } \\
\text { liści } \\
\text { - dziennikarze }\end{array}$ & $\begin{array}{l}\text { - ekonomiści } \\
\text { - liberałowie } \\
\text { - kadra departamentów handlowych } \\
\text { - kadry partyjne } \\
\text { - stratedzy z oficjalnych think-tanków }\end{array}$ \\
\hline $\begin{array}{l}\text { Główne } \\
\text { postulaty }\end{array}$ & $\begin{array}{l}\text { - polityka światowa jest z natury rywali- } \\
\text { zacją } \\
\text { - strategia ChRL jest nastawiona na obję- } \\
\text { cie dogodniej pozycji w świecie } \\
\text { - rywalizacja mocarstw przechodzi ewo- } \\
\text { lucję od rywalizacji wojskowej do gospo- } \\
\text { darczej } \\
\text { - opozycja w stosunku do dominacji ame- } \\
\text { rykańskiej }\end{array}$ & $\begin{array}{l}\text { - współzależność ekonomiczna } \\
\text { (gospodarcza) } \\
\text { - specjalizacjia produkcji } \\
\text { - pokój i rozwój jako główna tendencja } \\
\text { współczesnych stosunków międzynaro- } \\
\text { dowych }\end{array}$ \\
\hline
\end{tabular}

Źródło: Chen Mumin,op. cit., s. 155.

Oczywiste jest, że obecne elity władzy postrzegają świat zewnętrzny przez pryzmat chińskich reform. Zarówno realiści, jak i liberałowie podnoszą te kwestie we wzajemnych dyskusjach. Racjonaliści twierdzą, że otwarcie na świat kapitalistyczny i szybki wzrost gospodarczy doprowadził do niestabilności i kryzysu w chińskim społeczeństwie. Z uwagi na wewnętrzne problemy Chiny powinny regulować otwarcie na świat oraz zmniejszać zależność wzrostu gospodarczego od eksportu. Liberałowie natomiast, co oczywiste, podkreślają doniosłość i wielkie znaczenie reform oraz otwarcia na świat i budowy relacji

\footnotetext{
${ }^{47}$ Shen Jiru, Zhongguo bu dang „Bu Xiansheng” - Dangdai Zhongguo de guoji zhanlue wenti [Chiny nie są „Panem Nie” - o problemach współczesnej strategii Chin na arenie międzynarodowej], Jinri Zhongguo Chubanshe, Beijing 1998, s. 405, oraz Chen Mumin, op. cit., s. $158-159$.

${ }^{48}$ Ibidem.
} 
międzynarodowych w oparciu o koncepcje heping yu fazhang. Warto również odnieść się do formułowanej od listopada 2003 r. koncepcji pokojowego wzrastania (heping jueqi). Zheng Bijian - jej autor - uzasadniał: „Od rozpoczęcia reform i otwarcia na świat Chiny podjęły wyzwania nie tylko pasujące do warunków wewnętrznych, ale również potwierdzające się we współczesnym świecie. Nowa chińska strategia pokojowego wzrastania będzie realizowana poprzez budowę socjalizmu z chińską charakterystyką oraz udziału w procesach ekonomicznej globalizacji, ${ }^{49}$. W podobnym duchu wypowiadał się premier Wen Jiabao podczas swojego wykładu na Uniwersytecie Harvarda w grudniu 2003 r. ${ }^{50}$

Jednak w opinii niektórych elit „pokojowe wzrastanie” nie odpowiada sytuacji międzynarodowej. Takie stanowisko prezentował wiceprezydent Zeng Qinghong, który podczas swojego wystąpienia na forum Organizacji Narodów Międzynarodowych w kwietniu 2004 r. nie odniósł się do lansowanej wówczas w Chinach koncepcji ${ }^{51}$. Dwa aspekty nowej polityki wzbudziły szczególne obawy: kwestia Tajwanu oraz reakcja Stanów Zjednoczonych na ewentualny konflikt w Cieśninie Tajwańskiej. Pod koniec sierpnia 2004 r. w „Xuexi Shibao” - gazecie Centralnej Szkoły Partyjnej afiliowanej przy Komitecie Centralnym Komunistycznej Partii Chin - opublikowano artykuł, w którym poruszono wymienione problemy: „Jeśli tajwańscy separatyści będą domagać się «niepodległości Tajwanu», jeśli siły trzecie - Stany Zjednoczone zagrożą chińskiemu zjednoczeniu, nie będzie miejsca na pokojowe wzrastanie" ${ }^{\text {,52 }}$.

\section{$* * *$}

Podejmując wysiłek modernizacji państwa elity chińskie same ulegają takim procesom, w tym również w sferze intelektualnej i koncepcyjnej. Prowadzi to do akceptacji zachodnich wzorców, m.in. w obszarze światowej gospodarki. Procesy westernizacji, jak się wydaje, zachodzą również w myśleniu chińskich elit o świecie zewnętrznym, czego wymownym przykładem jest porównanie wydawanych między 1999 a 2005 r. podręczników dotyczących stosunków międzynarodowych. Powrót do pozycji Chin sprzed XIX w. może, choć nie musi, prowadzić do wzrostu zagrożenia konfliktem militarnym. Jeśli założymy,

${ }^{49}$ R. L. S u e t t in ge r, The Rise and Descent of “Peaceful Rise”, „The China Leadership Monitor" 2004, No. 12, www.chinaleadershipmonitor.org/20044/rs.pdf (stan z 19.10.2006).

${ }^{50}$ Wen Jiabao Hafo yanjiang tichu guanzhi wenming duihua he wenhua jiaoliu, 12/11/03 [Wen Jiabao w wykładzie na Harvardzie podkreśla konieczność dialogu między kulturami i wymiany między kulturami], http://www.china-embassy.org/chn/zt/FIRST/t56067.htm (stan z 22.10.2006).

${ }^{51}$ R. L. S u e $\mathrm{t} \mathrm{t}$ in g e r, The Rise and Descent...

${ }^{52}$ Ibidem. 
że Chińczycy przyjmą koncepcję Hansa Morgentaua o wzmacnianiu i prezentowaniu na zewnątrz siły państwa, może się okazać, że np. spór o Wyspy Paracelskie i Sprately zakończy się dominacją wojskową ChRL na Morzu Południowo-Chińskim. Z drugiej jednak strony dyplomacja chińska inaczej podchodzi do każdej sytuacji decyzyjnej, adaptując rodzime wzorce, chociażby czerpania ze Sztuki wojennej Sun Zi lub pism innych chińskich strategów. 